\title{
Pengembangan Media Pembelajaran Video Berbasis Microsoft Office Power Point Pada Materi Objek IPA Dan Pengamatannya Untuk SMP Kelas VII
}

\author{
Nisah Turrahmi, Fahmi Yahya, Muhammad Erfan. \\ Program Studi Pendidikan Fisika \\ Universitas Samawa Sumbawa Besar \\ Sumbawa Besar, Indonesia \\ Email : annisah.turrahmi.17@gmail.com
}

\begin{abstract}
Abstrak - Pembelajaran IPA dapat didukung oleh penggunaan media. Penggunaan media pembelajaran video dapat membantu guru dalam menyampaikan materi IPA agar lebih praktis serta mampu merangsang pemikiran yang memicu pemahaman siswa agar lebih mudah memahami setiap konsep-konsep materi IPA. Berdasarkan hal tersebut, penelitian ini bertujuan untuk: (1) mengetahui tingkat kelayakan media pembelajaran video berbasis microsoft office power point pada materi objek IPA dan pengamatannya; (2) mengetahui respon siswa terhadap media pembelajaran video berbasis microsoft office power point pada materi objek IPA dan pengamatannya.

Penelitian ini merupakan penelitian pengembangan (research and development) dengan menggunakan model Borg\&Gall. Namun dalam pelaksanaannya penelitian hanya sampai pada tahap keenam, yaitu hanya sampai pada tahap uji coba terbatas. Instrumen yang digunakan adalah angket. Validasi produk dilakukan oleh ahli media, ahli materi serta guru IPA sebagai praktisi dan diujikan di kelas VII sebanyak 10 siswa. Data yang diperoleh dianalisis secara deskriptif kuantitatif dan deskripsi kualitatif.

Hasil penelitian menunjukkan bahwa pengembangan media pembelajaran video berbasis Microsoft Office Power Point layak digunakan sebagai media pembelajaran alternatif dalam pembelajaran IPA. Kelayakan video pembelajaran berdasarkan penilaian ahli materi mendapatkan nilai rata-rata 3,83 termasuk dalam kategori baik, penilaian ahli media mendapatkan nilai rata-rata 3,81 termasuk dalam kategori baik, penilaian oleh guru IPA mendapatkan nilai rata-rata 4,28 termasuk dalam kategori sangat baik, penilaian kelayakan video pembelajaran berdasarkan uji coba pada siswa SMP memperoleh skor rata-rata 4,50 termasuk dalam kategori sangat baik.
\end{abstract}

Kata kunci: video, media pembelajaran, Microsoft Office Power Point, objek IPA.

\section{Pendahuluan}

Perkembangan media pendidikan telah berlangsung secara sangat cepat, dan membentuk budaya baru secara signifikan dalam proses pembelajaran. Budaya baru ini, langsung atau tidak langsung akan mempengaruhi siswa mengikuti proses pembelajaran. Ciri yang paling mendominasi adalah munculnya komponen budaya indrawi yang utuh, meliputi melihat, mendengar, merasakan-menyentuh dan bereksplorasi. Menurut Arsyad (2013:16) menyatakan bahwa media pembelajaran paling besar pengaruhnya bagi indera dan lebih dapat menjamin pemahaman. Hal ini dapat dilihat dari bagaimana media tersebut mempengaruhi proses pembelajaran. Penggunaan media dalam proses belajar mengajar mampu mengubah paradigma bahasa yang dulunya cenderung mengajar, kemudian berubah menjadi bahasa media yang bersifat membujuk, menggetarkan hati, dan penuh dengan resonansi, irama, cerita, dan gambar yang tervisualisasikan. Siswa akan tertarik pada sifat-sifat proses pembelajaran yang auditif dan visualitatif.

Berdasarkan pendekatan teknologi pendidikan, media pengajaran menjadi daya tarik bagi dunia pendidikan. Ia tidak hanya sebagai alat bantu, akan tetapi juga sebagai alat menarik minat peserta didik serta penyalur pesan-pesan pendidikan. Walaupun tanpa bantuan guru, media pendidikan dapat menghadapi siswa dalam belajar di kelas.

Media pendidikan merupakan salah satu komponen yang tidak bisa diabaikan dalam mengembangkan sistem pengajaran yang sukses (Thoifuri, 2007:167). Dalam suatu proses belajar mengajar, dua unsur yang amat penting adalah metode mengajar dan media pembelajaran. Kedua aspek ini saling berkaitan. Bahan pengajaran yang dimanipulasikan dalam bentuk media pengajaran dapat menarik minat belajar peserta didik dan menjadikan peserta didik belajar sambil bermain dan bekerja.

Salah satu jenis media yang sering digunakan dalam pembelajaran adalah Microsoft Office Power Point. Menurut Arsyad (2013) Microsoft Power Point merupakan salah satu software yang dirancang khusus 
untuk menampilkan program multimedia yang menarik, mudah dalam pembuatan dan mudah dalam penggunaan. Dengan memaksimalkan penggunaan fitur Microsoft power point dengan baik, maka materi dapat disampaikan dengan baik.

Berdasarkan observasi yang dilakukan di SMPN 2 Sumbawa ditemukan bahwa sarana dan prasarana yang terdapat sudah memadai. Hal ini dapat dilihat dari secara keseluruhan kelas sudah terdapat LCD proyektor yang bisa digunakan untuk mendukung penggunaan media pembelajaran dalam proses belajar mengajar. Namun belum semua pendidik di SMPN 2 sumbawa memanfaatkan media dalam pembelajaran, bahkan masih ada guru yang masih menggunakan metode mengajar secara konvensional.

Hal ini berdampakan pada berkurangnya minat belajar siswa pada mata pelajaran tertentu khususnya mata pelajaran IPA. Menurut Aritonang (2012) IPA berada pada urutan kedua sebagai mata pelajaran yang masuk kedalam katergori kurang diminati oleh siswa SMP karena merupakan pembelajaran abstrak dan dianggap sulit. Hal ini dapat dilhat dari hasil belajar siswa SMPN 2 sumbawa bahkan pada materi yang sederhana atau mudah dalam mata pelajaran IPA masih ada siswa yang memperoleh nilai di bawah Kriteria Ketuntasan Minimal (KKM). Pada Kelas VII-5 dari 36 siswa yang memperoleh nilai dibawah KKM sebanyak 25 siswa, dan pada kelas VII-4 dari 36 siswa 16 siswa memperoleh nilai di bawah Krieria Keuntasan Minimal (KKM).

Berdasarkan hal tersebut sehingga peneliti mengambil penelitian untuk mengembangkan software persentasi yang biasa di gunakan oleh guru. Adapun judul penelitian pengembangan media pembelajaran video berbasis Microsoft Office power point pada materi objek IPA dan pengamatannya. Peneliti mengembangkan microsoft office power point menjadi sebuah video pembelajaran dengan tujuan mempermudah guru dalam menyampaikan materi dan membangkitkan semangat belajar siswa pada mata pelajaran IPA. Mengingat bahwa karakteristik siswa di SMPN 2 sumbawa lebih tertarik belajar dengan menggunakan video. Menurut Beshnizen dan Van Puthen (2012) dalam Nuari, Fandy dan Ardi Havid (2014) menggambarkan bahwa video memiliki kapasitas untuk memotivasi siswa.

Berdasarkan latar belakang masalah, maka yang menjadi rumusan masalahnya adalah : (1) layakkah media pembelajaran video berbasis Microsoft Office Power Point pada materi objek IPA dan pengamatannya untuk SMP kelas VII dengan sub bahasan pengukuran sebagai bagian dari pengamatan ?; (2) Sebarapa besar respon siswa terhadap penggunaan media pembelajaran video berbasis Microsoft office power point pada materi objek IPA dan pengamatannya untuk SMP kelas VII dengan sub bahasan pengukuran sebagai bagian dari pengamatan?

Berdasarkan rumusan masalah di atas, adapun tujun penelitian: (1) Untuk mengetahui tingkat kelayakan media pembelajaran video berbasis Microsoft Office Power Point pada materi objek IPA dan pengamatannya dengan sub bahasan pengukuran sebagai bagian dari pengamatan; (2) Untuk mengetahui respon siswa terhadap media pembelajaran video berbasis Microsoft Office Power Point pada materi objek IPA dan pengamatannya dengan sub bahasan pengukuran sebagai bagian dari pengamatan.

\section{TINJAUAN PUSTAKA}

\section{A. Media Pembelajaran}

Menurut Azhar Arsyad (2013:3) kata media berasal dari bahasa latin medius yang secara harfilah berarti 'tengah', 'perantara' atau 'pengantar' dan dalam bahasa Arab media adalah perantara atau pengantar pesan dari pengirim kepada penerima pesan. Association of education and communication technology atau AECT mendefinisikan media sebagai segala bentuk dan saluran yang digunakan untuk menyampaikan pesan atau informasi.

Pembelajaran dapat diartikan sebagai interaksi yang edukatif antara pendidik dengan sumber belajar sebagai usaha sadar seorang pendidik untuk mencapai tujuan pembelajaran yang diharapkan. Pembelajaran secara sederhana dapat diartikan sebagai produk interaksi berkelanjutan antara pengembangan dan pengalaman hidup. Pembelajaran dalam makna kompleks adalah usaha sadar dari seorang guru untuk membelajarkan siswanya dalam rangka mencapai tujuan yang diharapkan (Trianto, 2010:17).

Berdasarkan beberapa definisi di atas, maka dapat disimpulkan bahwa media pembelajaran merupakan alat yang dapat membantu guru dalam menjelaskan dan menyampaikan informasi dalam proses pembelajaran sehinggga tujuan tujuan pembelajaran dapat tercapai atau terlaksana.

\section{B. Microsoft Office Power Point}

Menurut Isroi dalam Kurniawati (2011) Power Point merupakan salah satu media untuk menyampaikan presentasi. Power Point dapat merupakan bagian dari keseluruhan presentasi maupun menjadi satu-satunya sarana penyampaian informasi. Pendapat lain diungkapkan oleh Djamarah dalam Purnamasari (2013:17) "media power point adalah alat bantu guru guna mencapai tujuan pembelajaran dimana merupakan media visual yang menampilkan slide, gambar atau lukisan atau symbol." Sejalan dengan Djamarah, Sianipar (2004:1) menyatakan bahwa power point mempunyai kemudahan untuk menginpor file, gambar, suara dan movie, membuat lompatan dari tampilan satu ke tampilan yang lain. Menurut Mangkulo (2011) dengan Power point, para pengajar dapat mendesain aplikasi yang dapat membantu para pelajar untuk lebih mudah berinteraksi dengan materi pelajaran yang disampaikan.

Berdasarkan pendapat para ahli di atas, maka dapat disimpulkan bahwa Microsoft Office Power Point merupakan salah satu media pembelajaran yang dapat membantu guru dalam menyampaikan materi. Media ini sering digunakan oleh guru karena programnya yang mudah dikelolah, mudah dalam melakukan editing materi, dan bahasa pemrograman yang digunakan mudah dimengerti/tidak rumit. 


\section{C. video}

Menurut Munir (2012: 289) menyatakan bahwa istilah video berasal dari bahasa latin yaitu dari kata vidi atau visum yang artinya melihat atau mempunyai daya penglihatan. Dalam kamus bahasa indonesia video adalah teknologi pengiriman sinyal elektronik dari suatu gambar bergerak.

Agnew dan Kellerman dalam Munir (2012:290) mendefinisikan video sebagai media digital yang menunjukkan susunan atau urutan gambar-gambar dan memberikan ilusi, gambaran serta fantasi pada gambar yang bergerak.

Berdasarkan pendapat para ahli di atas, maka dapat disimpulkan bahwa video merupakan salah satu media digital/teknologi penangkapan, perekaman, pengolahan, penyimpanan, pemindahan, dan perekonstruksian urutan gambar diam dengan menyajikan adegan-adegan dalam gerak secara elektronik.

\section{Objek IPA}

Menurut Widodo, (2016) Pengamatan Objek dengan menggunakan indra merupakan kegiatan penting untuk mendeskripsikan suatu benda. Ada beberapa bentuk Objek dalam IPA yang penting dalam perkembangan IPA diantaranya:

1. pengukuran

Menurut Widodo, Wahono dkk (2016:8) menyatakan bahwa mengukur merupakan kegiatan membandingkan suatu besaran yang diukur dengan besaran sejenis yang dipakai sebagai satuan. Menurut Winarsih, anni dkk (2008) Pengukuran adalah membandingkan suatu besaran dengan suatu satuan. Pengukuran merupakan kegiatan membandingkan besaran dengan besaran yang lainnya (Giancolli, 2001: 8). Berdasarkan pendapat para ahli tersebut dapat disimpulkan bahwa pengukuran merupakan kegiatan membandingkan suatu besaran dengan besaran sejenis yang digunakan sebagai satuan.

2. System satuan internasional

Menurut Sutarno, (2013:2) satuan didefinisikan sebagai pembanding dalam suatu pengukuran besaran. Setiap besaran mempunyai satuan masig-masing, tidak mungkin dalam 2 besaran yang berbeda mempunyai satuan yang sama. Apabila ada dua besaran berbeda mempunyai satuan sama maka besaran itu pada hakekatnya adalah sama.

\section{Besaran}

Menurut Widodo (2016:8) Besaran adalah segala sesuatu yang dapat diukur atau dihitung, dinyatakan dengan angka dan mempunyai satuan. Besaran adalah ukuran fisis suatu benda yang dinyatakan secara kuantitas (Winarsih, anni dkk: 2008). Berdasarkan pendapa kedua ahli dapat disimpulkan bahwa besaran merupakan segala sesuatu yang dapat diukur.

\section{METODE PENELITIAN}

Rancangan pengembangan video pembelajaran berbasis Microsoft office power point menggunakan model Borg\&Gall. Model Research and Development (R\&D) versi Borg and Gall dalam pendidikan sesuai dengan yang dijelaskan oleh Sugiyono (2015 : 35-37) terdiri dari 10 tahap, yakni (1) penelitian dan pengumpulan informasi awal; (2) perencanaan; (3) pengembangan produk awal; (4) Uji Coba Pendahuluan; (5) Revisi Produk Awal; (6) Uji Coba Terbatas; (7) Revisi Produk Operasional; (8) Uji Coba Operasional; (9) Revisi Produk Akhir; dan (10) Disemenasi \& Implementasi yang diadopsi dari model penelitian pengembangan oleh Borg\&Gall dapat dilihat pada Bagan 1.

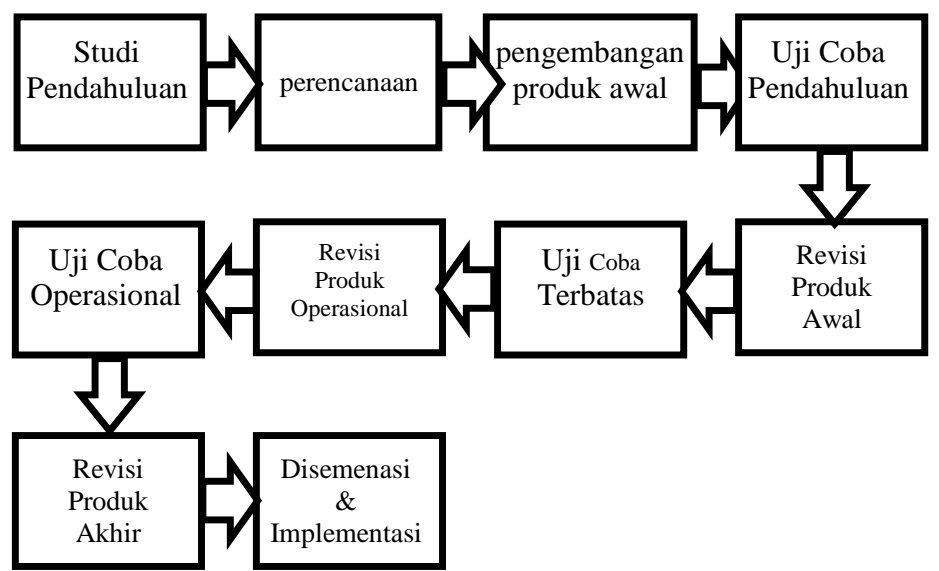

Bagan 1 Tahapan Penelitian dan Pengembangan Menurut Borg\&Gall (1989)

Penelitian yang dilakukan oleh peneliti dibatasi pada Enam tahap dari sepuluh tahapan model penelitian pengembangan tersebut, dirancang sebagai model penelitian pengembangan media pembelajaran video berbasis Microsoft Office Power Point pada materi objek IPA dan pengamatannya dengan pokok bahasan pengukuran sebagai bagian dari pengamatan. Hal ini dikarenakan terbatasnya waktu yang dibutuhkan untuk melakukan penelitian lebih lanjut dan penelitian in hanya sampai pada tahap mengetahui kelayakan produk dan respon siswa.

\section{Uji Coba Produk}

\section{Desain Uji Coba}

Desain uji coba yang digunakan adalah video pembelajaran dari pengembangan Microsoft Office Power Point. video yang diberikan sebelum proses pembelajaran berlangsung melalui pengembangan produk penelitian. Dalam rancangan penelitian ini sampel hanya terdiri dari satu kelompok saja.

\section{Subjek Uji Coba}

Subjek coba dalam penelitian dan pengembangan ini terdiri dari validator produk dan subjek coba produk. Uraian subjek uji coba adalah sebagai berikut.

a. Validator Produk Pengembangan

1. Validator pertama selaku dosen Fisika Universitas Samawa.

2. Validator kedua selaku dosen Fisika Universitas Sumbawa.

3. Validator ketiga selaku guru Mata Pelajaran IPA SMPN 2 Sumbawa. 


\section{b. Subjek Coba Produk}

Subjek coba produk dalam penelitian dan pengembangan ini adalah 10 siswa kelas VII SMPN 2 Sumbawa tahun ajaran 2016/2017.

\section{Instrumen Penelitian}

Instrumen yang digunakan dalam pengumpulan data uji coba produk pengembangan berbentuk kuisioner/angket. Angket yang digunakan pada validasi isi produk pengembangan terdiri dari tiga bagian, yaitu: bagian pertama berupa petunjuk penggunaan angket penilaian dan aspek yang dinilai dari angket, bagian kedua berupa lembar saran, dan bagian ketiga kesimpulan dari validator mengenai aspek yang dinilai. Angket yang digunakan pada uji coba terbatas produk pengembangan terdiri dari penilaian respon siswa.

\section{Teknik Analisis Data}

Teknik analisis data yang digunakan dalam penelitian ini adalah teknik rata-rata.

\section{a) Kelayakan Produk}

Kategori-kategori jawaban validator pada angket akan dihitung nilai rata-ratanya dan disajikan dalam bentuk persentase. Skor yang diperoleh pada pengisian angket dianalisis dengan menggunakan teknik perhitungan nilai rata-rata menurut Sudjana (2014: 144) adalah sebagai berikut.

$$
\bar{X}=\frac{\sum x}{n}
$$

Keterangan:

$$
\begin{aligned}
\bar{X} & =\text { nilai rata-rata } \\
\sum x & =\text { total skor jawaban validator } \\
\mathrm{n} & =\text { jumlah validator }
\end{aligned}
$$

Nilai rata-rata jawaban yang diperoleh dapat disimpulkan tingkat kelayakan produk yang dikembangkan dengan menggunakan kriteria hasil analisis kelayakan produk.

\section{b) Respon Subjek}

Kategori-kategori jawaban siswa pada angket juga menggunakan perhitungan rata dan hasil analisis kemudian disajikan dalam bentuk presentase. Skor yang diperoleh pada pengisian angket dianalisis dengan menggunakan teknik perhitungan nilai rata-rata menurut Sudjana (2014: 144) adalah sebagai berikut.

$$
\bar{X}=\frac{\sum x}{n}
$$

Keterangan:

$$
\begin{aligned}
\bar{X} & =\text { nilai rata-rata } \\
\sum x & =\text { total skor jawaban siswa } \\
\mathrm{n} & =\text { jumlah siswa }
\end{aligned}
$$

Nilai rata-rata jawaban yang diperoleh dapat disimpulkan tingkat kemudahan produk yang dikembangkan dengan menggunakan kriteria hasil analisis pengolahan angket.

\section{HASIL DAN PEMBAHASAN}

\section{Deskripsi hasil Studi Pendahuluan}

Berdasarkan observasi yang telah dilakukan, didapatkan hasil bahwa (a) guru telah menggunakan media dalam pembelajaran namun kurang variatif; (b) sebagian guru juga masih menggunakan metode yang konvensional seperti metode ceramah dan mencatat dipapan tulis dirasa tidak efektif; (c) Siswa juga merasa jenuh dalam pembelajaran IPA sehingga perhatian siswa tidak terpusat kepada guru maupun terlibat dalam kegiatan pembelajaran; (d) minimnya penggunaan media dalam kegiatan belajar mengajar sehingga siswa lebih cepat bosan dan tidak fokus pada materi pelajaran yang sedang diajarkan; (e) sedangkan pada mata pelajaran IPA siswa susah untuk memahami materi karena siswa hanya diajak untuk berkhayal tanpa melihat contoh nyata atau animasi yang dapat mendukung pemahaman materi: (f) sarana dan prasana disekolah dapat dikatakan sangat memadai karena secara menyeluruh diruang kelas mempunyai LCD laptop proyektor.

Berdasarkan hasil wawancara dengan beberapa siswa diperoleh bahwa (a) siswa merasa IPA sebagai mata pelajaran yang kurang menarik. (b) ketika PBM berlangsung siswa sering merasa mengantuk; dan (c) siswa lebih tertarik terhadap media seperti video digunakan dalam pembelajaran IPA. Berdasarkan hasil tersebut, maka pengembangan power point sangat diperlukan sebagai media pembelajaran untuk membantu guru dalam kegiatan pembelajaran, sehingga dapat memusatkan perhatian siswa dalam belajar IPA.

\section{Perancangan}

Perancangan draft produk pengembangan diawali dengan menyusun storyboard produk pengembangan. Penyusunan storyboard berfungsi memudahkan peneliti dalam mengembangkan produk pengembangan Cuplikan story board produk pengembangan dapat dilihat pada Lampiran 3

Keseluruhan komponen yang telah disusun dalam tahap perancangan produk pengembangan kemudian dikembangkan menjadi power point. Power point dirancang dengan menggunakan Microsoft Office Power Point 2016. Setelah power point selesai dirancang tahap selanjutnnya yaitu membuat animasi teks (materi), gambar, scene, memasukkan suara (Audio Record), dan mendesain background dengan menggunakan ikon-ikon yang terdapat pada power point. Langkah terakhir yaitu mengconvert power point ke dalam video dengan format $m p 4$. Setelah proses convert video, tahap selanjutnya adalah menambahkan instrumen musik ke dalam video. Musik di dalam video berfungsi sebagai backsound pada video pembelajaran Penggabungan backsound dengan video menggunakan Adobe Premiere Pro 5.

Pembuatan animasi teks dan gambar pada tiap slide power point menggunakan ikon animations. Dalam ikon animations terdapat tiga jenis efek animasi yang dapat digunakan yaitu efek masukan (Entrance Effects), efek setelah masukan/sudah berada dalam slide (Emphasis Effects), dan efek keluar (Exit Effects).

Animasi pergantian slide (scene) pada power point dibuat dengan menggunakan ikon Transitions. Untuk membuat animasi background pada power point dengan menggunakan ikon design. Untuk mengubah tampilan background klik ikon Format Background. Langkah selanjutnya dari proses pengembangan adalah mengembangkan bagian awal produk (intro) Sebelumnya, peneliti juga menambahkan halaman introduction pengenalan media sebelum mulai masuk 
ke halaman utama. Peneliti juga menambahkan musik selama halaman introduction pengenalan berjalan.

Langkah selanjutnya yaitu mengubah (menconver) power point menjadi video dengan cara mengklik ikon menu file lalu pilih menu export klik create a video kemudian akan keluar menu yang berkaitan dengan video seperti menu pilihan untuk mengatur kualitas video, suara, dan waktu pergantian slide.

\section{Deskripsi hasil Pengembangan Microsoft Office}

Power Point ke dalam media pembelajaran video.

Hasil pengembangan Microsoft Office Power Point yang telah dilakukan adalah berupa video pembelajaran materi penggukuran sebagai bagian dari pengamatan yang dapat digunakan oleh siswa untuk belajar secara mandiri. Berikut ini disajikan deskripsi media pembelajaran video berbasis Microsoft Office Power Point yang dihasilkan.

\section{a. Hasil Scene Materi}

Penentuan materi yang akan digunakan pada produk harus dikerucutkan menjadi beberapa sub bahasan, materi yang bahas pada produk ini adalah Objek IPA dan Pengamatannya, yang terdiri dari empat sub bahasan yaitu penyelidikan IPA, pengukuran sebagai bagian dari pengamatan, besaran pokok, dan besaran turunan. Peneliti mengambil sub bahasan kedua yang digunakan pada pembuatan produk karena materi pengukuran adalah hal yang paling mendasar dan sangat penting dalam perkembangan IPA.

Scene berisi materi pengukuran sebagai bagian dari pengamatan. Materi disajikan berdasarkan indikator yang telah ditentukan dan tujuan pembelajaran yang ingin dicapai. Penyampaian materi melalui teks, gambar dan penjelasan (Audio Record). Penentuan materi berdasarkan pada buku pegangan yang digunakan oleh guru pada kegiatan proses belajar mengajar (PBM). Penyusunan materi pada scene disusun secara sistematis berdasarkan urutan indikator dan tujuan pembelajaran.

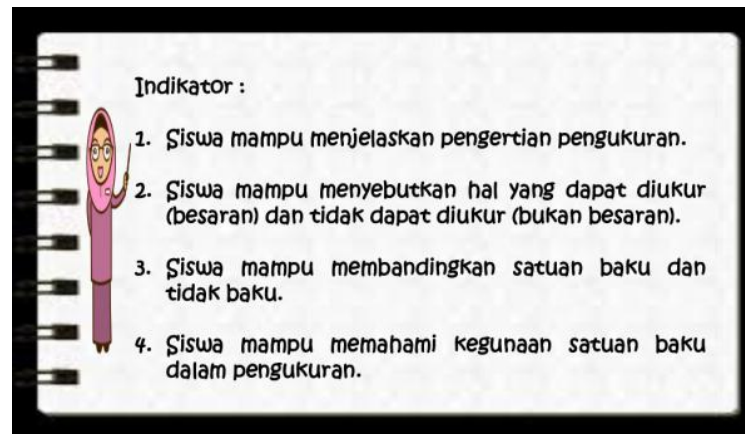

Gambar 1. Scene Indikator Materi Pengukuran Sebagai Bagian dari Pengamatan.

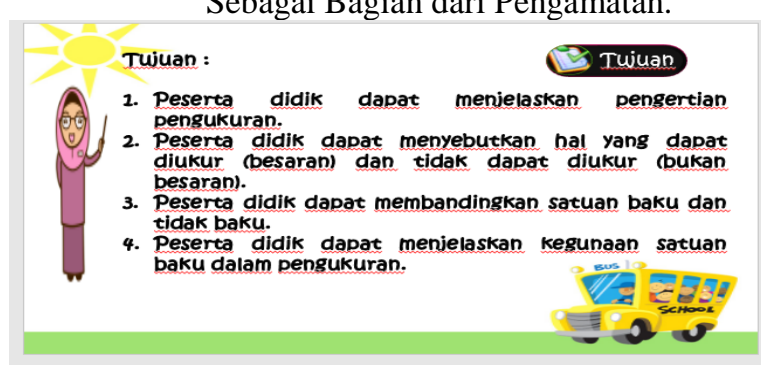

Gambar 2. Scene Tujuan Pembelajaran Materi Pengukuran Sebagai Bagian dari Pengamatan

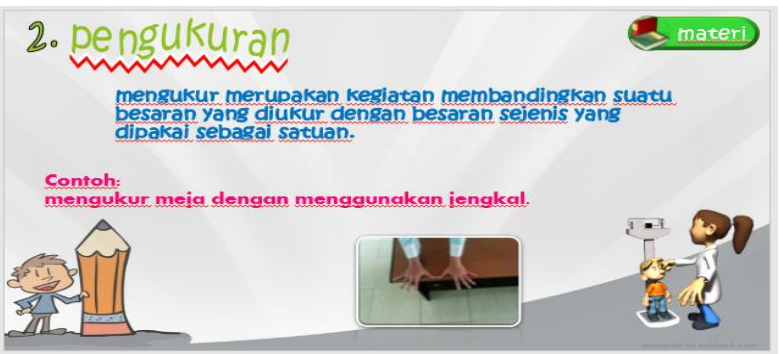

Gambar 3. Scene materi berdasarkan indikator dan tujuan pembelajaran yang pertama.

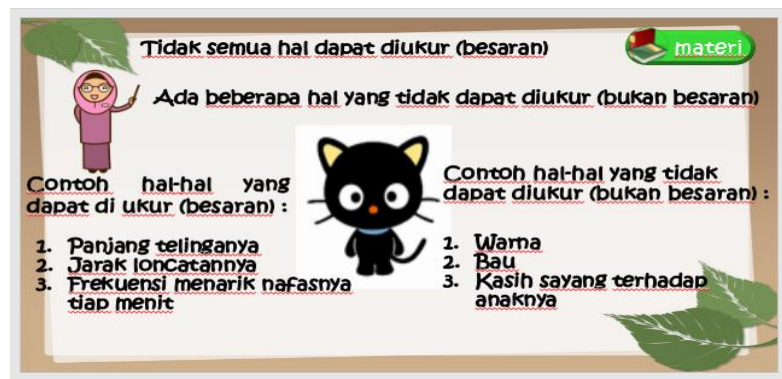

Gambar 4. Scene materi berdasarkan Indikator dan Tujuan Pembelajaran yang Kedua

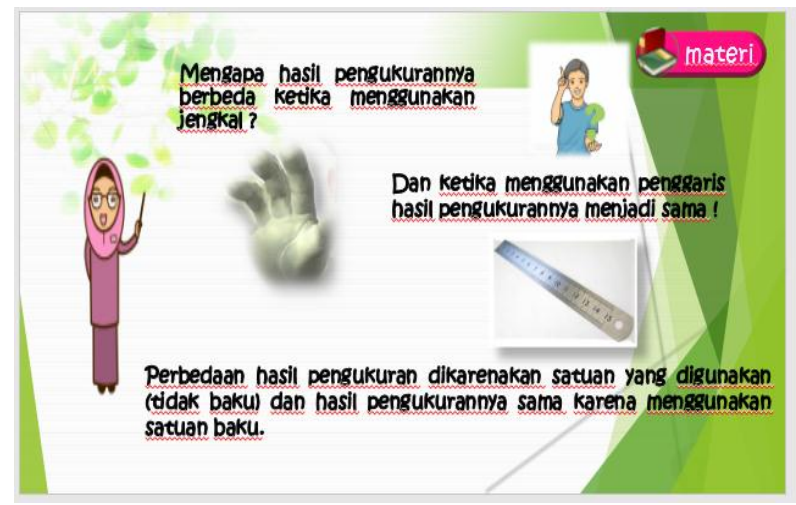

Gambar 5. Scene Materi Berdasarkan Indikator dan Tujuan Pembelajaran yang Ketiga.

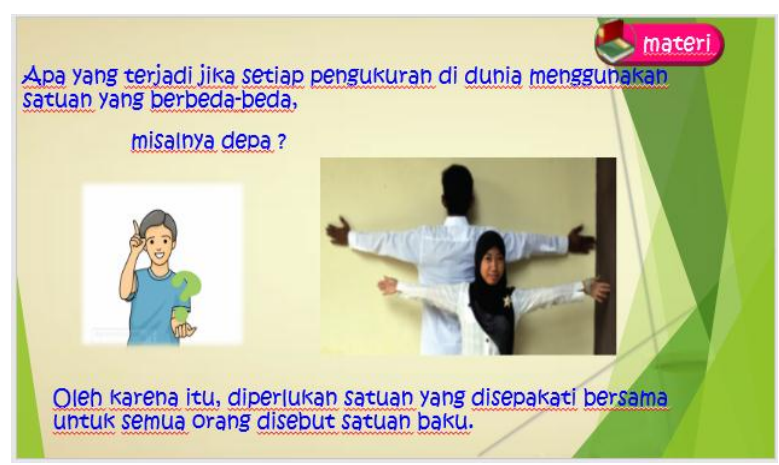

Gambar 6. Scene Materi Berdasarkan Indikator dan Tujuan Pembelajaran yang Keempat.

\section{b. Durasi}

Durasi waktu yang digunakan dalam video pembelajaran ini terdiri dari dua yaitu yang pertama durasi animasi dan durasi pergantian scene. Pengaturan durasi sangat penting dan harus dilakukan dengan tepat, seksama dan sesuai. Hal ini dikarenakan apabila durasi yang digunakan terlalu cepat atau terlalu lambat maka hasil dari video pembelajaran menjadi kurang maksimal dan bisa mempengaruhi ketepatan antara penjelesan 
dengan animasi teks dan gambar yang muncul terkait materi.

\section{c. Hasil scene Latihan}

Scene berisi latihan yang digunakan untuk mengetahui apakah siswa sudah benar-benar paham dengan materi yang disajikan dalam produk. Latihan terdiri dari 5 soal yang terkait dengan isi dari produk.

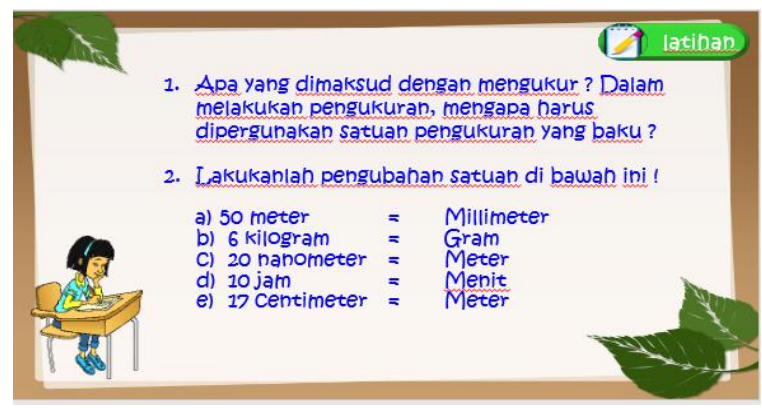

(a)

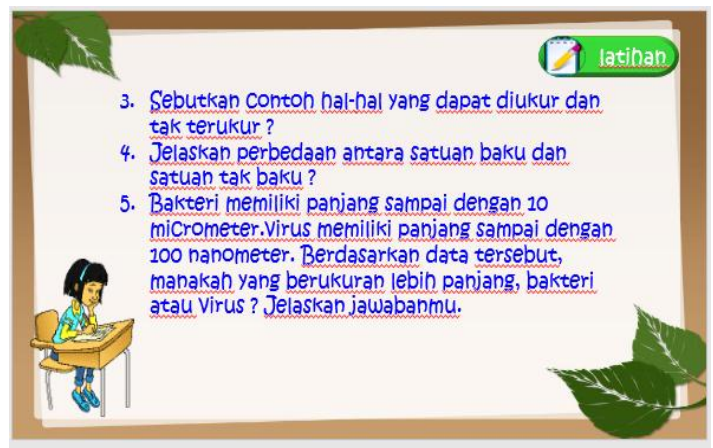

(b)

Gambar 7 (a) dan (b). Soal Latihan untuk tugas siswa.

\section{d. Penjelasan (audio).}

Penjelasan yang digunakan pada produk ini merupakan penjelasan berupa Audio Record. Sebelum suara diinsert ke dalam produk terlebih dahulu suara direkam dengan menggunakan perekam suara pada handphone. Penjelasan yang disampaikan menyesuaikan dengan buku pegangan guru IPA.

\section{Analisis kelayakan produk}

Pada tahap ini, Produk media pembelajaran berbasis power point yang telah dikembangkan selanjutnya melalui tahap validasi oleh pakar atau ahli terdiri dari ahli materi, ahli media dan ahli praktisi. Validasi dilakukan untuk menganalisi kualitas dan kelayakan produk yang telah dikembangkan peneliti. Ahli media terdiri dari dua validator, ahli materi terdiri dari dua validator, dan ahli praktisi yaitu guru maa pelajaran IPA SMP kelas VII.

Penilaian oleh ahli materi memuat kelayakan aspek materi, aspek penyajian, aspek bahasa, aspek konstruksi, aspek tampilan serta aspek konstruksi. Secara keseluruhan validasi komik dari keseluruhan aspek mendapat skor 3,83 dengan kategori baik. Ratarata skor validasi oleh kedua validator pada masingmasing aspek dapat dilihat pada tabel 1 .
Tebel 1. Rata-rata skor validasi ahli materi

\begin{tabular}{|l|c|c|}
\hline Aspek penilaian & Skor rata-rata & Kategori \\
\hline Materi & 3,80 & Baik \\
\hline Penyajian & 3,80 & Baik \\
\hline Bahasa & 4,00 & Baik \\
\hline Konstruksi & 3,83 & Baik \\
\hline Tampilan & 3,92 & Baik \\
\hline teknis & 3,67 & Baik \\
\hline
\end{tabular}

Penilaian oleh ahli media memuat kelayakan aspek kebahasaan, aspek serta aspek tampilan menyeluruh. Secara keseluruhan validasi komik dari keseluruhan aspek mendapat skor 3,81 dengan kategori baik. Ratarata skor validasi oleh kedua validator pada masingmasing aspek dapat dilihat pada tabel 2.

Tebel 2. Rata-rata skor validasi ahli media

\begin{tabular}{|l|c|c|}
\hline Aspek penilaian & Skor rata-rata & Kategori \\
\hline Kebahasaan & 4,00 & Baik \\
\hline Konstruksi & 3,83 & Baik \\
\hline Tampilan & 3,92 & Baik \\
\hline Teknis & 3,67 & Baik \\
\hline
\end{tabular}

Penilaian oleh guru mata pelajaran IPA memuat kelayakan aspek materi, aspek bahasa, aspek konstruksi, aspek tampilan serta aspek konstruksi. Secara keseluruhan validasi komik dari keseluruhan aspek mendapat skor 4,28 dengan kategori sangat baik. Rata-rata skor validasi oleh kedua validator pada masing-masing aspek dapat dilihat pada tabel 3 .

Tebel 3. Rata-rata skor validasi guru IPA

\begin{tabular}{|l|c|c|}
\hline Aspek penilaian & Skor rata-rata & Kategori \\
\hline Materi & 4,40 & Sangat Baik \\
\hline Kebahasaan & 4,33 & Sangat Baik \\
\hline Konstruksi & 4,50 & Sangat Baik \\
\hline Tampilan & 4,67 & Sangat Baik \\
\hline Teknis & 3,50 & Cukup Baik \\
\hline
\end{tabular}

5. Analisis Respon Siswa terhadap Penggunaan Media Pembelajaran Video Berbasis Power Point

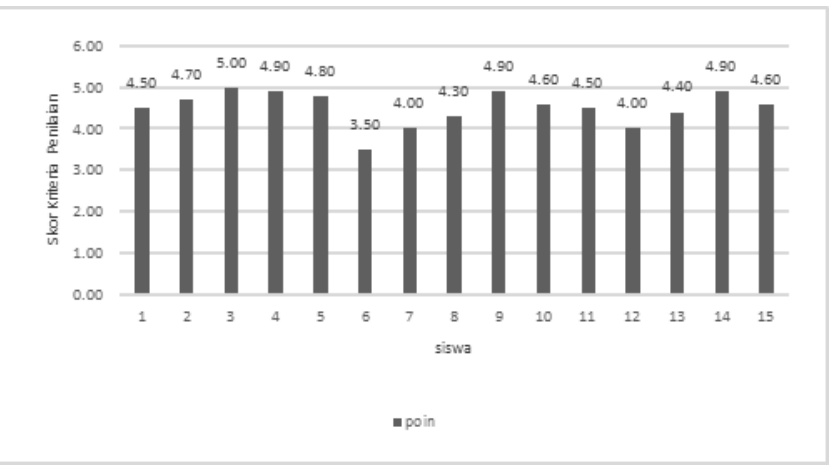

Berdasarkan hasil uji coba terbatas, vvideo penbelajaran yang dikembangkan dapat dinyatakan sudah baik atau valid. Hal ini diketahui dari nilai ratarata keseluruhan butir penilaian kualitas dan kemampuan produk pada uji coba terbatas asesmen formatif berbantuan komputer telah mencapai rentang angka 4,26-5,00. Hasil data yang demikian 
menunjukkan bahwa produk sudah layak untuk digunakan.

\section{PENUTUP}

Berdasarkan hasil penelitian pengembangan dapat disimpulkan bahwa pengembangan media pembelajaran video berbasis Microsoft Office Power Point pada materi objek IPA dan pengamatannya untuk SMP kelas VII layak digunakan sebagai media pembelajaran alternative dalam pembelajaran IPA yang dapat digunakan untuk siswa belajar secara mandiri dan membantu guru dalam penyampaian materi. Kelayakan video pembelajaran berbasis Microsoft Office Power Point berdasarkan penilaian ahli materi pada keseluruhan aspek mendapatkan nilai rata-rata 3,83 termasuk dalam kategori baik, penilaian ahli media keseluruhan aspek mendapatkan nilai rata-rata 3,81 termasuk dalam kategori baik. Penilaian oleh guru fisika pada keseluruhan aspek mendapatkan nilai ratarata 4,28 termasuk dalam kategori sangat baik.

Penilaian kelayakan media pembelajaran video berbasis Microsoft Office Power Point berdasarkan hasil uji coba terbatas yang dilakukan pada 10 siswa SMP memperoleh skor rata-rata 4,50 termasuk dalam kategori sangat baik. Berdasarkan penilaian di atas, media pembelajaran video berbasis Microsoft Office Power Point layak digunakan sebagai media pembelajaran IPA SMP kelas VII.

Penelitian yang dilakukan memiliki beberapa kekurangan. Untuk itu, peneliti menyarankan agar Media ini dapat dikembangkan pada materi lain yang lebih luas yaitu pada sub materi yang lain dengan menggunakan pembahasan materi yang sama atau dengan pembahasan materi lain. Mengingat bahwa media pembelajaran ini tidak hanya digunakan di dalam kelas akan tetapi dapat pula digunakan di luar kelas. Adapun Kreasi dari animations, transitions, design background, and backsound bisa ditambahkan agar media semakin menarik. Selain itu, Pemberian soal latihan dipebanyak, beragam dan mendalam untuk lebih mengukur kemampuan siswa pada materi yang disampaikan. Serta Penyampaian poin-poin materi disajikan lebih rincih supaya siswa memperoleh pemahaman yang lebih kompleks.

\section{REFERENSI}

[1] Aritonang, keke T. 2008. Minat dan Motivasi dalam Meningkakan Hasil Belajar Siswa. Jakarta: Jurnal Pendidikan Penabur No.10.

[2] Arsyad, Azhar 2013. Media Pembelajaran. Jakarta: PT. Raja Grafindo Persada.

[3] Giancoli, Douglas C. 2001. Fisika Edisi Kelima. Jakarta: Erlangga.

[4] Kurniawati, Ayu. 2011. Pengembangan Media Pembelajaran Menggunakan Microsoft Power Point Pada Mata Pelajaran Tekhnologi Informasi dan Komunikasi Siswa Kelas VIII di SMP Negeri 2 Plupuh Sragen. Fakultas Teknik, Universitas Negeri Yogyakarta.
[5] Mangkulo, Hengky Alexander. 2011. Aplikasi Belajar Interaktif dengan Power Point. Jakarta: PT Elex Media Komputindo.

[6] Munir. 2012. Multimedia Konsep dan Aplikasi dalam Pendidikan. Bandung. ALFABETA Bandung.

[7] Nuari, fandy dan Ardi Hamid. 2014. Using Camtasia Studio 8 to Produce Learning Video To Teach English Through E-Learning. JELT Journal, University Of Padang, Vol 3 (1).

[8] Purnamasari, Ita. 2013. Keefektifan Model Pembelajaran CTL (Contextual Teaching and Learning) Berbantuan Media Powerpoint, CD Interaktif, dan Macromedia Flash Ditinjau dari Hasil Belajar Matematika di MAN 1 Semarang Tahun Ajaran 2012/2013. Universitas IKIP PGRI Semarang, Semarang.

[9] Putra, Nusa. 2015. Research \& Development: Penelitian dan Pengembangan: Suatu Pengantar. Jakarta: PT Raja Grafindo Persada.

[10] Setyosari, Punaji. 2015. Metode Penelitian: Pendidikan \& Pengembangani. Jakarta: Prenadamedia Group.

[11] Sianipar, Pandapotan. 2004. Menggunakan Microsoft Office Power Point 2003. Jakarta. Elex Media Komputindo.

[12] Sudjana, Nana. 2014. Penilaian Hasil Proses Belajar Mengajar. Bandung: PT Remaja Rosdakarya Offset.

[13] Sugiyono. 2015. Metode Penelitian \& Pengembangan: Research \& Development. Bandung: Alfabeta.

[14] Sutarno, 2013. Fisika Untuk Universitas. Yogyakarta: Graha Ilmu.

[15] Thoifuri. 2007. Menjadi Guru Inisiator. Semarang: RaSAIL Media Group.

[16] Trianto. 2010. Mendesain Model Pembelajaran Inovatif-Progresif. Jakarta: kencana.

[17] Widodo, Wahono. dkk. 2016. Ilmu Pengetahuan Alam. Jakarta: Pusat Kurikulum \& Pembukuan, Balitbang, Kemdikbud.

[18] Winarsih, anni dkk. 2008. Ilmu Pengeahuan Alam. Jakarta: Pusat Perbukuan- Departemen Pendidikan Nasional. 